\title{
Competition and critical periods in spring sugar beet cultivation
}

\author{
José Mansilla Martínez ${ }^{1,2}$, José-Arturo de Juan Valero ${ }^{1 *}$, Alfonso Domínguez Padilla ${ }^{1}$ \\ María-Raquel Picornell Buendía ${ }^{*}$
}

\begin{abstract}
${ }^{1}$ School of Advanced Agricultural Engineering, Castilla - La Mancha University, Campus Universitario s/n, E02071, Albacete, Spain ${ }^{2}$ retired, School of Advanced Agricultural Engineering, Castilla - La Mancha University, Campus Universitario s/n, E02071, Albacete, Spain
\end{abstract}

Received: March 7, 2015

Accepted: September 3, 2015

\begin{abstract}
High yields with low costs require that sugar beets be kept free of weeds, during critical periods, using labor or chemical treatments. Since the critical periods for this crop in Castilla - La Mancha (Spain) are unknown, the first goal of this study was to determine the effect of early and late competition on yield. The second goal was to determine the critical periods, while taking into consideration the semiarid climatic conditions of this region. Two irrigation farms located in the province of Albacete are dedicated to sugar beet cultivation. These two farms were chosen to carry out the tests March $\left(140,000-150,000\right.$ seeds $\cdot$ ha $\left.^{-1}\right)$ and harvested in October. Two simultaneous and complementary experiments were carried out in each year and farm. Two scenarios were considered with eight different treatments each. In the first one (With Weeds Until - WWU), plots were infested by weeds up to a certain date. In the second one (Free of Weeds Until - FWU), plots were kept free of weeds up to a certain date. For each test, a randomised experimental blocked field was designed and there were four repetitions, each of them containing eight elemental plots (12 $\left.\mathrm{m}^{2}\right)$. Each plot was weeded by hand or weeds were left to grow till a definite date.The results indicated that a $1 \%$ loss of yield was reached in the early competition after 14 days, while a loss of $5 \%$ was reached after a period of 41 days after it was infested. The results also indicated that in late competition, if a crop is kept clean for 124 days and it is infested afterwards, a $1 \%$ loss is reached. However, the loss increases to $5 \%$ if the plot is kept clean for 111 days. For a $1 \%$ loss the critical period is 110 days and 70 days for a $5 \%$ loss.
\end{abstract}

Key words: critical period, irrigation, modelling, semiarid, weed, yield

\section{Introduction}

The level of weed infestation during crop development is a factor that affects the final yield. Depending on the development stage of the crop, the effect of weed competition is different. The critical period is defined as the amount of time free of weeds which is required by a crop to prevent a reduction of yield and/or quality due to the interference in lighting and nutrition caused by these plants (Pardo 1990). To obtain the highest yield of the crop at the lowest cost, the field must be kept weed-free either by hand or by chemical processing during this period. The critical period ranges according to the infested species, the density of the species, the cultivated species, the location, and the year (Suso et al. 1999).

The sugar beet crop is very sensitive to the competition of weeds due to its slow initial development. Nowadays, the critical period when this crop is sowed in autumn is known: (1) under rainfed conditions: between 2 and 16 authentic cultivation leaves (between 21 and 95 days after crop emergence); (2) under irrigation conditions: between 4 and 16 authentic cultivation leaves (be-

*Corresponding address:

MRaquel.Picornell@hotmail.com tween 50 and 130 days after crop emergence) (Gutiérrez Sosa and Reina 1993).

In areas where sowing is carried out in spring, the critical period occurs between the crop emergence and 5-8 weeks later. A sugar beet yield is not affected if weeds are controlled during the first 5-8 weeks (early control). Later weed emergences do not influence the final yield since they are controlled naturally by the crop (Scott et al. 1979; Mobarak et al. 2012).

In the Castilla-La Mancha (Spain) region, sugar beets are sown in spring. The beets are irrigated because this region is semiarid. The objectives of this study are to determine: (1) the period of early competition; (2) the period of late competition; and (3) the critical period for sugar beets.

\section{Materials and Methods}

Two farms ("Los Llanos" and "Casablanca") specialising in sugar beet cultivation were chosen for the trials. Both farms are located in the province of Albacete. The weed flora was monitored for two consecutive years in eight ex- 
perimental fields irrigated by a sprinkling system (pivot system). According to the Thornthwaite climatic classification, the climate is defined as D B2 d b3. According to the Papadakis agroecological classification, the climate is av M TE Me. In the "Los Llanos" farm, the soil was classified as: Nature: Aridisols; Subnature: Argids; Big Group: Petroargids; Subgroup: Xeric Petroargids. The mediumlow fertility of the soil is typical in this area due to its lithology and climatic conditions. Sugar beets were planted on both farms in March (140,000 and 150,000 seeds · ha $\left.{ }^{-1}\right)$, and the roots were collected in October.

Two simultaneous and complementary experiments were carried out each year at each experimental farm. For each test, a randomised experimental blocked field with four repetitions was designed. Each repetition contained eight elemental plots $\left(4 \mathrm{~m} \times 3 \mathrm{~m}=12 \mathrm{~m}^{2}\right)$ weeded by hand or the weeds were left to grow up to a definite date (T1 and $\mathrm{T} 8$ treatments). In the experiment named With Weeds Until (WWU), the weeds were allowed to spread in the elemental fields until $50 \%$ of the sugar beet plants emerged. Later, the plots were weeded and kept clean until harvest day. T1 was kept free of weeds until the harvest; T2-T7 were infested from sowing, up to a different previously determined date (different for each treatment); and T8 was infested during the whole growing period. In the experiment called Free of Weeds Until (FWU), the opposite was done. The fields were kept free of weeds by hand from $50 \%$ of the crop emergence until determined dates when weeds were allowed to infest the plots - up to harvest time. While T1 was infested until the harvest, T2-T7 treatments were maintained free of weeds until a certain date. The treatment, T8 was kept free of weeds during the whole growing season. To monitor the phenological stages of the weed flora, weed samples were periodically taken from the experimental plots. For sampling, five $0.33 \times 0.33 \mathrm{~m}^{2}$ areas were collected at each of the four repetitions, when the natural infestation date for each of the treatments was fulfilled (T1-T8; Tables 1, 2). Weeding and infestation dates of the tested treatments are shown in tables 1 and 2.

A description of the technological stages of the sugar beet was carried out using periodic sample outlets following the scales of Mohler (1997), Meier et al. (1993) and López Bellido (2003). For example, C2-D2, is a phenological stage corresponding to two true leaves, and a root weight between 200 and $300 \mathrm{~g} \cdot$ plant $^{-1}$.

To study the infestation components and the assessment parameters, many samples were collected during the development period of the crop. Several parameters were analysed, such as: weed density (D) (total number of plants per unit area, expressed in plants $\left.\cdot \mathrm{m}^{-2}\right)$, specific density (De) (number of plants of the same weed species per unit area, expressed in plants $\cdot \mathrm{m}^{-2}$ ), relative sample frequency (Frm) (number of plots in which a given species appears), and the relative specific frequency ( $\mathrm{Fr}$ ) (ratio of the number of plants of each species to the total number of plants in a plot, in a square metre; is the ratio of specific density and density) (Pujadas 1986; Saavedra 1987; Recasens 1994). To determine the total dry crop biomass (Tdbw), the beet plants in each replicate were counted and two of them were pulled up. The samples were dried in a forced air circulation oven, at $105^{\circ} \mathrm{C}$ temperature for $24 \mathrm{~h}$.

The critical competition period was calculated as the difference between the early competition period and the late competition period.

Once the sugar beet yield was obtained, some models were selected for estimating the yield of the roots (Mansilla 2005). These models use harvest production as the dependent variable (in this case, the root dry biomass), and the physiological time as the independent variable. The competition period length $(t)$ was expressed in days or as growing degree-days (GDD, $\left.{ }^{\circ} \mathrm{C}\right)$. The non-linear regressions used in this study were: general logistic equation, turning point logistic equation, turning point Gompertz equation, Weibull equation, and the hyperbolic equation.

The selected model had to fulfill the following statistical analysis: the model hypothesis test, independence, normality, and homocedasticity (Huet et al. 1992; Romero and Zúnica 1993). Moreover, a validation process was carried out comparing simulated with observed data. Lastly, the third condition was to confirm that the model hypothesis that was mentioned before, was achieved, which was tested by the "remainder analysis". The statistical software used or the calibration and validation of the models were SPSS for Windows, v. 10.06 and Statgraphics, v. 5.0.

\section{Results}

The young/early period of the sugar beets (period of time that the crop requires to develop 20 or more leaves) needed around 71 to 85 days to complete its cycle. This corresponds to 825 and 842 growing degree-days $\left({ }^{\circ} \mathrm{C}\right)$ respectively, depending on the year and field tested (ground temperature or zero vegetation, $6^{\circ} \mathrm{C}$ ). The whole growing cycle required from 2,177 to 2,287 growing degree-days $\left({ }^{\circ} \mathrm{C}\right)$ to be complete, which corresponds to $160-184$ days after crop emergence.

For infestation levels, various parameters such as De and Fr were developed. During the first year of the WWU scenario, the genus Setaria was the most common weed in the first five treatments at "Los Llanos" (Table 1). In "Casablanca", Chenopodium album L. and Setaria spp. were the most abundant species; up to T6. The species Solanum nigrum L. were also important due to the higher thermal demand. Other abundant species were Amaranthus blitoides Watson and Sorghum halepense (L.) Pers. (Table 2).

In the early stage of competition (WWU) for the test fields and for the years, the species found in the majority of the plots and the species with the highest infestation levels were Amaranthus retroflexus L., Ch. album, and Setaria spp. During the second year of the study, however, the presence of $A$. retroflexus decreased. Other species such as Salsola kali L. and S. nigrum appeared as isolated cases (Table 3).

In the late stage of competition (FWU), the most abundant species during the first year were $S$. nigrum and $C h$. album at both farms, and A. retroflexus at "Los Llanos", and Setaria spp. at "Casablanca". In the experiments carried out during the second year, S. nigrum and Ch. album were also found (Table 3). 
Table 1. Composition of weeds species in the scenario With Weeds Until (WWU) in treatments (T1 to T8) “Los Llanos" fields. Year 1. Sample: $09 / 08$

\begin{tabular}{|c|c|c|c|c|c|c|c|c|c|c|c|c|c|c|c|c|}
\hline \multirow{2}{*}{ Species } & \multicolumn{2}{|c|}{$\mathrm{T} 1(07 / 04)$} & \multicolumn{2}{|c|}{$\mathrm{T} 2(25 / 04)$} & \multicolumn{2}{|c|}{ T3(10/05) } & \multicolumn{2}{|c|}{$\mathrm{T} 4(25 / 05)$} & \multicolumn{2}{|c|}{ T5(07/06) } & \multicolumn{2}{|c|}{ T6(21/06) } & \multicolumn{2}{|c|}{$\mathrm{T} 7(12 / 07)$} & \multicolumn{2}{|c|}{ T8(09/08) } \\
\hline & De & $\mathrm{Fr}$ & De & $\mathrm{Fr}$ & De & Fr & De & $\mathrm{Fr}$ & De & $\mathrm{Fr}$ & De & $\mathrm{Fr}$ & De & $\mathrm{Fr}$ & De & Fr \\
\hline Am. r. & - & - & 23.5 & 16.3 & 18.5 & 9.0 & 23.0 & 10.7 & 25.0 & 13.1 & 33.0 & 21.0 & 13.0 & 12 & 12.5 & 21.5 \\
\hline Am. b. & - & - & - & - & - & - & 18.0 & 8.3 & 9.5 & 5.0 & 5.5 & 3.5 & 4.0 & 3.7 & 3.5 & 6.3 \\
\hline Ch. a. & - & - & 4.5 & 3.1 & 58.0 & 22.2 & 64.5 & 20.9 & 100.0 & 52.6 & 109.0 & 69.4 & 67.5 & 62.5 & 34.5 & 59.5 \\
\hline St. spp. & - & - & 113.0 & 78.8 & 90.5 & 44.0 & 100.0 & 46.6 & 53.0 & 27.7 & 7.5 & 4.8 & 21.5 & 19.9 & - & - \\
\hline Kch. s. & - & - & 2 & 1.4 & 1.5 & 0.7 & 1.0 & 0.5 & 0.5 & 0.3 & - & - & - & - & - & - \\
\hline Ss. k. & - & - & 0.5 & 0.3 & - & - & - & - & 1.0 & 0.5 & - & - & - & - & - & - \\
\hline Sl. n. & - & - & - & - & 34.0 & 16.5 & - & - & - & - & 2 & 1.3 & 2.0 & 1.8 & 6.5 & 11.2 \\
\hline Pg. a. & - & - & - & - & 3.0 & 1.5 & 4.5 & 2.0 & 1.5 & 0.8 & - & - & - & - & - & - \\
\hline Fm. o. & - & - & - & - & - & - & 0.5 & 0.2 & - & - & - & - & - & - & - & - \\
\hline Ht. a. & - & - & - & - & - & - & 0.5 & 0.2 & - & - & - & - & - & - & - & - \\
\hline Sb. i. & - & - & - & - & - & - & 0.5 & 0.2 & - & - & - & - & - & - & - & - \\
\hline Sg.h. & - & - & - & - & - & - & - & - & - & - & - & - & - & - & 1.0 & 1.7 \\
\hline
\end{tabular}

$\mathrm{T} 1=$ treatment free of weeds up to harvest; $\mathrm{T} 2-\mathrm{T} 7$ = treatments infested up to a fixed date; $\mathrm{T} 8=$ treatment with weeds from sowing up to harvest. Specific density (De, plants $\left.\cdot \mathrm{m}^{-2}\right)$; Relative frequency $(\mathrm{Fr}$, one species percentage regarding the species total in one plot) Am. r. = Amaranthus retroflexus L.; Am. b. = Amaranthus blitoides Watson; Ch. a. = Chenopodium album L.; St. spp. = Setaria spp.; Kch. s. = Kochia scoparia Schrader.; Ss. k. = Salsola kali L.; Sl. n. = Solanum nigrum L.; Pg. a. = Polygonum aviculare L.; Fm. o. = Fumaria officinalis L.; Ht. a. = Helianthum annuus L.; Sb. i. = Sisymbrium irio L.; Sg. h. = Sorghum halepense (L.) Pers.

Table 2. Composition of weeds species in the scenario Free of Weeds Until (FWU) in treatments (T1 to T8) "Casablanca" fields. Year 1. Sample: $16 / 09$

\begin{tabular}{|c|c|c|c|c|c|c|c|c|c|c|c|c|c|c|c|c|}
\hline \multirow{2}{*}{ Species } & \multicolumn{2}{|c|}{$\mathrm{T} 1(22 / 04)$} & \multicolumn{2}{|c|}{$\mathrm{T} 2(13 / 05)$} & \multicolumn{2}{|c|}{ T3(27/05) } & \multicolumn{2}{|c|}{$\mathrm{T} 4(13 / 06)$} & \multicolumn{2}{|c|}{$\mathrm{T} 5(27 / 06)$} & \multicolumn{2}{|c|}{ T6(10/07) } & \multicolumn{2}{|c|}{ T7(06/08) } & \multicolumn{2}{|c|}{ T8(16/09) } \\
\hline & $\mathrm{De}$ & $\mathrm{Fr}$ & $\mathrm{De}$ & Fr & De & Fr & $\mathrm{De}$ & Fr & De & Fr & $\mathrm{De}$ & Fr & De & Fr & $\mathrm{De}$ & Fr \\
\hline Am. r. & - & - & 0.6 & 0.7 & - & - & - & - & - & - & 0.62 & 6.67 & - & - & - & - \\
\hline Am. b. & 8.1 & 5.7 & 2.5 & 2.9 & 0.6 & 3.4 & 4.4 & 21.2 & 2.50 & 17.6 & 1.9 & 20.0 & 1.2 & 16.7 & 0.6 & 20.0 \\
\hline Ch. a. & 88.7 & 62.8 & 37.5 & 44.1 & 8.1 & 46.4 & 15.0 & 72.7 & 3.75 & 35.3 & 1.25 & 13.3 & 1.25 & 16.7 & 1.9 & 60.0 \\
\hline St. spp. & 38.7 & 27.4 & 39.4 & 46.3 & 3.7 & 21.4 & 4.38 & 21.2 & 3.12 & 29.3 & 3.7 & 40.0 & 16.7 & 33.3 & - & - \\
\hline Kch. s. & - & - & - & - & - & - & - & - & - & - & - & - & - & - & - & - \\
\hline Ss. k. & - & - & - & - & - & - & - & - & - & - & - & - & - & - & - & - \\
\hline Sl. n. & - & - & 4.3 & 5.1 & 4.4 & 25.0 & 3.8 & 18.1 & 1.88 & 17.6 & 19.0 & 20.0 & 1.2 & 16.7 & 0.6 & 20.0 \\
\hline Pg. a. & - & - & - & - & - & - & - & - & - & - & - & - & - & - & - & - \\
\hline Fm. o. & - & - & - & - & - & - & - & - & - & - & - & - & - & - & - & - \\
\hline Ht. a. & - & - & - & - & - & - & - & - & - & - & - & - & - & - & - & - \\
\hline Sb. i. & - & - & - & - & - & - & - & - & - & - & - & - & - & - & - & - \\
\hline Sg. h. & 5.6 & 4.0 & 0.6 & 0.7 & 0.6 & 3.6 & - & - & - & - & - & - & 1.2 & 16.7 & - & - \\
\hline
\end{tabular}

$\mathrm{T} 1$ = treatment infested up to harvest; $\mathrm{T} 2-\mathrm{T} 7$ = treatments free of weeds up to a certain date; $\mathrm{T} 8=$ treatment free of weeds during the whole growing cycle.

Specific density (De plants $\cdot \mathrm{m}^{-2}$ ); Relative frequency (Fr, one species percentage regarding the species total in one parcel). Am. r. = Amaranthus retroflexus L.; Am. b. = Amaranthus blitoides Watson; Ch. a. = Chenopodium album L.; St. spp. = Setaria spp.; Kch. s. = Kochia scoparia Schrader.; Ss. k. = Salsola kali L.; Sl. n. = Solanum nigrum L.; Pg. a. = Polygonum aviculare L.; Fm. o. = Fumaria officinalis L.; Ht. a. = Helianthum annuus L.; Sb. i. = Sisymbrium irio L.; Sg h. = Sorghum halepense (L.) Pers. 
Table 3. Weeds species found in treatments $\mathrm{T} 1$ to $\mathrm{T} 8$

\begin{tabular}{|c|c|c|c|c|c|c|c|c|}
\hline \multirow{4}{*}{ Species } & \multicolumn{8}{|c|}{ Sampling relative frequency $(\mathrm{Fr})$} \\
\hline & \multicolumn{4}{|c|}{ With Weeds Until (WWU) } & \multicolumn{4}{|c|}{ Free of Weeds Until (FWU) } \\
\hline & \multicolumn{2}{|c|}{ "Los Llanos" } & \multicolumn{2}{|c|}{ "Casablanca" } & \multicolumn{2}{|c|}{ “Los Llanos" } & \multicolumn{2}{|c|}{ “Casablanca” } \\
\hline & year 1 & year 2 & year 1 & year 2 & year 1 & year 2 & year 1 & year 2 \\
\hline Am. r. & 93.7 & 75.5 & 61.4 & 21.0 & 84.4 & 60.0 & 6.3 & 50.0 \\
\hline Am. b. & 40.6 & 28.1 & 64.5 & 22.0 & 15.6 & 25.0 & 46.8 & 45.0 \\
\hline Ch. a. & 87.5 & 59.4 & 96.9 & 100.0 & 81.2 & 55.0 & 75.0 & 35.0 \\
\hline St. spp. & 71.9 & 62.5 & 96.9 & 53.0 & - & 30.0 & 62.5 & 45.0 \\
\hline Kch. s. & 34.4 & - & - & - & - & - & - & - \\
\hline Ss. k. & 9.4 & 50.0 & 12.5 & 22.0 & 3.1 & 10.0 & - & - \\
\hline Sl. n. & 25.0 & 21.9 & - & 19.0 & 100.0 & 25.0 & 71.8 & 45.0 \\
\hline Pg. a. & 21.9 & - & - & - & 6.2 & - & - & - \\
\hline Fm. o. & 3.1 & 15.6 & - & - & - & - & - & - \\
\hline Ht. a. & 3.1 & 3.1 & - & 16.0 & - & - & - & 10.0 \\
\hline Sb. i. & 3.1 & - & - & - & - & - & - & - \\
\hline Sg. h. & 3.1 & - & 3.1 & - & 62.6 & 45.0 & 9.4 & - \\
\hline Tdbw & $* *$ & $* *$ & ** & ** & $* *$ & ns & $*$ & $* *$ \\
\hline
\end{tabular}

$\mathrm{Fr}=$ sampling relative frequency or percentage of plots where the weed species was found (\%); Tdbw = total dry biomass of weeds $\left(\mathrm{g} \cdot \mathrm{m}^{-2}\right)$; Am. r. = Amaranthus retroflexus L.; Am. b. = Amaranthus blitoides Watson; Ch. a. = Chenopodium album L.; St. spp. = Setaria spp.; Kch. s. = Kochia scoparia Schrader.; Ss. k. = Salsola kali L.; Sl. n. = Solanum nigrum L.; Pg. a. = Polygonum aviculare L.; Fm. o. = Fumaria officinalis L.; Ht. a. = Helianthum annuus L.; Sb. i. = Sisymbrium irio L.; Sg. h. = Sorghum halepense (L.) Pers.

**highly significant $(\mathrm{p}<0.01)$, *significant $(\mathrm{p}=0.04), \mathrm{ns}=$ not significant

In tables 4 and 5 , the periods of early and late competition are shown, respectively, for the different yield losses.

Table 4 (early competence period) shows the progression of yield losses with time. So, at "Casablanca" during the first year, a $5 \%$ loss was reached after 22 days of competition, and after 22 days in the second year. A $10 \%$ loss was reached after 33 days during the first year and after 34 days in the second year. A 50\% yield loss was reached after 88 days in the first year and after 110 days in the second year. At the "Los Llanos" farm, the level of the forecasted losses progressed in a way similar to that at the "Casablanca" farm. At "Los Llanos", a 5\% loss was reached after 18 and 28 days in the first and second year, respectively. A $10 \%$ loss was reached after 26 and 45 days; and a 50\% loss after 67 and 136 days, in years 1 and 2 respectively.

Losses increased progressively according to a weedfree period decrease (Table 5, late competence period); at "Casablanca", the plot was kept free of weeds 113 and 115 days from emergence in the first and second year. The losses were 5\%; the 98 and 94 day yields were reduced $10 \%$, losing $50 \%$ of the yield when the plots were maintained free of weeds for 43 days. At the "Los Llanos" farm, a 5\% yield decrease occurred when the period which was free of weeds was 129 and 116 days. There was a $10 \%$ yield decrease when the period which was free of weeds was 98 to 119 days, and 50\% when plots were free of weeds for 71 days (first year) and 16 days (second year).

The different loss levels were obtained from the estimated losses in the WWU and FWU models (Table 6). The critical period decreases with the level of losses. The critical period is when there no losses caused by weeds. Due to yield decreases with the presence of weeds at any stage, the duration of the critical period coincides with the whole growing period. In consequence, for a suitable management of the crop, the level of tolerable losses was set between $1 \%$ and $5 \%$.

To calculate the competition model as a whole (WWU and FWU), the data from both experimental years were used. The equation reaching the best fit between observed and simulated data for both WWU and FWU scenarios, was the turning point logistic equation (Fig. 1):

$$
\mathrm{Y}=\mathrm{B}_{0} \cdot \exp \left\{-\exp \left[-\mathrm{B}_{2} \cdot\left(\mathrm{t}-\mathrm{B}_{3}\right)\right]\right\}
$$

where: $\mathrm{Y}$ - production per unit area $\left(\mathrm{g} \cdot \mathrm{m}^{-2}\right) ; \mathrm{t}$ - time elapsed (days) from the planting or crop emergence until a given time; $\mathrm{B}_{0}$ - linear scale parameter (asymptotic); $\mathrm{B}_{2}$ and $B_{3}-$ nonlinear parameters $\left(B_{2}\right.$ - initial growth rate and $\mathrm{B}_{3}$ - inflection point of the curve).

The independent variable used was: days from $50 \%$ of the sugar beet emergence. This variable offers better results than GDD (Mansilla 2005). All the estimated parameters were significant and the main statistical indicated-coefficients-of-determination were higher than $83 \%$ $\left(\mathrm{R}^{2}>85.27 \%\right.$ for the WWU scenario and $\mathrm{R}^{2}>83.57 \%$ for the FWU scenario) (Table 7).

The early and late competition periods simulated for the WWU and FWU models, with a loss of yield equal to $1 \%$ and $5 \%$, as well as the critical period expressed in days, are shown in table 8. According to the model: in the WWU scenario, a $1 \%$ loss occurs after 14 days of infestation, and losses increase up to $5 \%$ when the infestation period is 41 days. In the FWU scenario, it is required to keep the plot clean of weeds for 124 days, for a 1\% of yield decrease. Losses increase up to $5 \%$ when plots are free of weeds for 111 days. The critical period is 110 days to get losses of $1 \%$, and 70 days to increase losses up to $5 \%$. 
Table 4. Percentage of yield loss in the With Weeds Until (WWU) scenario

\begin{tabular}{|c|c|c|c|c|c|c|}
\hline \multirow{2}{*}{ Year } & \multirow{2}{*}{ Field } & \multicolumn{5}{|c|}{ Loss levels [\%] } \\
\hline & & 1 & 5 & 10 & 50 & 90 \\
\hline \multirow[t]{2}{*}{$1^{\circ}$} & "Casablanca" & 11 & 22 & 33 & 88 & 158 \\
\hline & PS & $\mathrm{C} 1$ & $\mathrm{C} 2$ & $\mathrm{C} 2$ & C9 & D3 \\
\hline \multirow[t]{2}{*}{$1^{\circ}$} & "Los Llanos" & 10 & 18 & 26 & 67 & 122 \\
\hline & PS & $\mathrm{C} 1$ & $\mathrm{C} 1$ & $\mathrm{C} 3$ & $\mathrm{C} 8$ & D2 \\
\hline \multirow[t]{2}{*}{$2^{\underline{o}}$} & "Casablanca" & 11 & 22 & 34 & 110 & 218 \\
\hline & PS & $\mathrm{C} 3$ & $\mathrm{C} 3$ & $\mathrm{C} 4$ & D3 & D4 \\
\hline \multirow[t]{2}{*}{$2^{o}$} & "Los Llanos" & 12 & 28 & 45 & 136 & 260 \\
\hline & PS & $\mathrm{C} 1$ & $\mathrm{C} 2$ & $\mathrm{C} 4$ & D2 & D4 \\
\hline Average & - & 11.00 & 22.50 & 34.50 & 100.25 & 189.50 \\
\hline $\mathrm{CV}$ & - & 7.42 & 18.32 & 22.76 & 29.52 & 32.43 \\
\hline
\end{tabular}

PS = phenological stage; $\mathrm{Ci}=$ young stage with " $\mathrm{i}$ " leaves; $\mathrm{Di}=\operatorname{root}$ weight $\left(\mathrm{D} 2=250 \mathrm{~g} \cdot\right.$ plant $^{-1} ; \mathrm{D} 3=300 \mathrm{~g} \cdot$ plant $^{-1}$; $\mathrm{D} 4=>400 \mathrm{~g} \cdot$ plant $\left.^{-1}\right) ; \mathrm{CV}=$ coefficient of variation $(\%)$

Table 5. Percentage of yield loss in the Free of Weeds Until (FWU) scenario

\begin{tabular}{|c|c|c|c|c|c|c|}
\hline \multirow{2}{*}{ Year } & \multirow{2}{*}{ Field } & \multicolumn{5}{|c|}{ Loss levels [\%] } \\
\hline & & 1 & 5 & 10 & 50 & 90 \\
\hline \multirow[t]{2}{*}{$1^{\mathrm{o}}$} & “Casablanca" & 133 & 113 & 98 & 43 & - \\
\hline & PS & D3 & D1 & C9 & $\mathrm{C} 2$ & - \\
\hline \multirow[t]{2}{*}{$1^{\mathrm{o}}$} & "Los Llanos" & 139 & 129 & 119 & 71 & 12 \\
\hline & PS & D2 & D1 & D1 & $\mathrm{C} 6$ & $\mathrm{C} 1$ \\
\hline \multirow[t]{2}{*}{$2^{\underline{o}}$} & "Casablanca" & 136 & 115 & 94 & - & - \\
\hline & PS & D3 & D2 & $\mathrm{C} 9$ & - & - \\
\hline \multirow[t]{2}{*}{$2^{\mathrm{o}}$} & "Los Llanos" & 136 & 116 & 98 & 16 & - \\
\hline & PS & D2 & D1 & C9 & $\mathrm{C} 1$ & - \\
\hline Average & - & 136.00 & 118.25 & 102.25 & 43.33 & - \\
\hline $\mathrm{CV}$ & - & 1.80 & 6.15 & 11.07 & 63.46 & - \\
\hline
\end{tabular}

$\mathrm{PS}=$ phenological stage; $\mathrm{Ci}=$ young stage with " $\mathrm{i}$ " leaves; $\mathrm{Di}=$ root weight $\left(\mathrm{D} 2,250 \mathrm{~g} \cdot\right.$ plant $^{-1} ; \mathrm{D} 3=300 \mathrm{~g} \cdot$ plant $^{-1}$;

$\mathrm{D} 4=>400 \mathrm{~g} \cdot$ plant $\left.^{-1}\right) ; \mathrm{CV}=$ coefficient of variation $(\%)$

Table 6. Critical periods of competence (in days)

\begin{tabular}{|c|c|c|c|c|c|c|}
\hline \multirow{2}{*}{ Year } & \multirow{2}{*}{ Field } & \multicolumn{5}{|c|}{ Loss levels [\%] } \\
\hline & & 1 & 5 & 10 & 50 & 90 \\
\hline \multirow[t]{2}{*}{$1^{o}$} & "Casablanca" & 122 & 91 & 65 & - & - \\
\hline & PS & C1-D3 & C2-D2 & C2-C9 & - & - \\
\hline \multirow[t]{2}{*}{$1^{\mathrm{o}}$} & "Los Llanos" & 129 & 111 & 93 & 4 & - \\
\hline & PS & C1-D2 & $\mathrm{C} 1-\mathrm{D} 1$ & C3-C9 & $\mathrm{C} 6-\mathrm{C} 8$ & - \\
\hline \multirow[t]{2}{*}{$2^{\mathrm{o}}$} & "Casablanca" & 125 & 93 & 60 & - & - \\
\hline & PS & C1-D3 & C3-D2 & $\mathrm{C} 4-\mathrm{C} 9$ & - & - \\
\hline \multirow[t]{2}{*}{$2^{\mathrm{o}}$} & "Los Llanos" & 124 & 88 & 53 & - & - \\
\hline & PS & $\mathrm{C} 1-\mathrm{D} 2$ & C2-D1 & C4-C9 & - & - \\
\hline Average & - & 125 & 95.75 & 67.75 & - & - \\
\hline $\mathrm{CV}$ & - & 2.35 & 10.83 & 25.88 & - & - \\
\hline
\end{tabular}

PS = phenological stage; $\mathrm{Ci}=$ young stage with "i" leaves; $\mathrm{Di}=\operatorname{root}$ weight $\left(\mathrm{D} 2,250 \mathrm{~g} \cdot\right.$ plant $^{-1} ; \mathrm{D} 3=300 \mathrm{~g} \cdot$ plant $^{-1}$;

$\mathrm{D} 4=>400 \mathrm{~g} \cdot$ plant $\left.^{-1}\right) ; \mathrm{CV}=$ coefficient of variation $(\%)$ 
Table 7. Coefficients of the mathematical models $\mathrm{Y}=\mathrm{a} /\{1+\exp [-\mathrm{b}(\mathrm{t}-\mathrm{c})]\}$ in the With Weeds Until (WWU) and Free of Weeds Until (FWU) scenarios

\begin{tabular}{ccc}
\hline Parameters & Model “WWU” & Model "FWU” \\
\hline a & $99.27^{*}$ & $110.16^{*}$ \\
b & $-0.03572^{*}$ & $0.02757^{*}$ \\
c & $115.64^{*}$ & $43.44^{*}$ \\
$\mathrm{R}^{2}$ & 85.27 & 83.57 \\
SE & 11.40 & 11.70 \\
MAE & 8.77 & 8.39 \\
\hline
\end{tabular}

$\mathrm{Y}=$ roots yield $\left(\mathrm{g} \cdot \mathrm{m}^{-2}\right) ; \mathrm{t}=$ physiological time, growing days since $50 \%$ of the sugar beets plants emergence up to weeding/weed infestation; $\mathrm{a}, \mathrm{b}, \mathrm{c}=$ coefficients of mathematical models; $\mathrm{R}^{2}$ = coefficient of determination $(\%)$; $\mathrm{SE}=$ standard error in the estimation; MAE $=$ absolute average error; and ${ }^{*} \mathrm{p}<0.05$

Table 8. Days of infestation required for 1 and $5 \%$ of yield loss in With Weeds Until (WWU) and Free of Weeds Until (FWU) scenarios, and critical period

\begin{tabular}{lcc}
\hline \multicolumn{1}{c}{ Periods } & $1 \%$ loss & $5 \%$ loss \\
\hline Early competition WWU & 14 & 41 \\
Late competition FWU & 124 & 111 \\
Critical period & 110 & 70 \\
\hline
\end{tabular}

\section{Discussion}

When weeds competed with sugar beets for 11, 22, and 100 days after crop emergence, the logistic model with a turning point, predicted an average loss of 1,5 , and $50 \%$ respectively. When the crop remained free of weeds for 43,118 , and 136 days after emergence, the estimated average losses were 50,5 , and $1 \%$ respectively. The average critical period for the $5 \%$ loss level was 95 days between the development of the cultivation C2-D2.

For both scenarios, the estimated model predicted that in the early stage of competition (WWU) for 14 and 41 days, a $1 \%$ and $5 \%$ loss were obtained, respectively and, in the late stage of competition (FWU), for 114 and 124 days, a $5 \%$ and $1 \%$ loss were obtained, respectively. For a 5\% loss level, 70 days was the competition period.

The critical period for weed control was between: 30 and 48 days after emergence (Duranti and Carone 1983; Odero et al. 2009, 2010); 24 and 36 days after emergence (Weaver and Tan 1983; Weaver 1984; Kropff et al. 1992); 24 and 36 days after transplanting (Friesen 1979; Weaver and Tan 1983). The researchers Salehi et al. (2006), indicated the presence of weeds during the entire growing season decreased a sugar-beet-root yield by $92.9 \%$ and $61.2 \%$ in 1999 and 2000, respectively. They added that the end of the critical period of weed control was 78 days in the first year, and 88 after planting for the second year. Mahmoud (2013) noted that the critical period of weed-sugar beet competition was between 2-10 weeks after emergence. This is the period in which sugar beets can tolerate weeds for only 2 weeks after sugar beet emergence and need a prolonged period of up to 10 weeks to be free from weeds.
One of the aims of this experiment, was to predict, with an acceptable level of accuracy, production losses from weed competition with crops. The predictions are from simple regression models to complex ecophysiological models.

\section{References}

Duranti A., Carone F. 1983. Rapporti di competitività tra pomodoro seminato (Lycopersicon esculentum Mill. cv. "Petegrò") ed infestanti. [Weed control of transplanted tomato for processing (Lycopersicon esculentum Mill. cv. "Petogro")]. Rivista di Ortoflorofrutticoltura Italiana 67 (3): 191-207. (in Spanish)

Friesen G.H. 1979. Weed interference in transplanted tomatoes (Lycopersicon esculentum). Weed Science 27: 11-13.

Gutiérrez Sosa M., Reina Mulero J. 1993. Determinación del período crítico de competencia de malas hierbas en la remolacha azucarera de siembra otoñal. [Establishment of the critical period for weed competition in autumn-sown sugar beet]. p. 299-302. In: Proceedings of the 1993 Congress of the Spanish Weed Science Society, Lugo, Spain, 1-3 December 1993, 342 pp. (in Spanish)

Huet S., Jolivet E., Messéan A. 1992. La régression non-linéarie: méthodes et applications en biologie. [The non-linear regression: methods and applications in biology]. INRA Editions, Paris, France, 236 pp. (in French)

Kropff M.J., Spitters C.J.T., Schneiders B.J., Joenije W., Groot W.D.E. 1992. An ecophysiological model for interspecific competition, applied to the influence of Chenopodium album L. on sugar beet. Weed Research 32 (6): 451-463.

López Bellido L. 2003. Cultivos Industriales. [Industrial Crops]. Mundi-Prensa, Madrid, Spain, 1071 pp. (in Spanish) 
Mansilla J. 2005. Efectos agronómicos de la duración y período de competencia entre la flora arvense y la remolacha azucarera (Beta vulgaris L. var. altissima Döll) de siembra primaveral. [Effects of agronomic duration and period of competition between flora arvense and sugar beet (Beta vulgaris L. var. altissima Doll) spring planting]. Ph.D. thesis, Castilla - La Mancha University, Albacete, Spain, 183 pp. (in Spanish)

Mahmoud O.M. 2013. Determination of critical period of weed competition with sugar beet (Beta vulgaris L.) and weed control. Ph.D. thesis, Faculty of Agriculture, Assiut University, Assiut, Egypt, 147 pp.

Meier U., Bachmann L., Buhtz, Hack H., Klose R., Märländer B., Weber E. 1993. Phänologische Entwicklungsstadien der Beta-Rüben (Beta vulgaris L. ssp.). Codierung und Beschreibung nach der erweiterten BBCH-Skala (mit Abbildungen). [Phenological growth stages of sugar beet (Beta vulgaris L. ssp.). Codification and description according to the general BBCH scale (with figures)]. Nachrichtenblatt des Deutschen Pflanzenschutzdienstes 45: 37-41. (in German)

Mobarak O.M., Galal A.H., Mekky M.S., Motagally F.M.F. 2012. Various methods for determining the critical period of weed competition to sugar beet 90: 4. In: Proceedings of the Fourth Conference of Field Crops Facing Future Challenges, Giza, Egypt, 28-30 August 2012, 15 pp.

Mohler C.L., Galford A.E. 1997. Weed seedling emergence and seed survival: separating the effects of seed position and soil modification by tillage. Weed Research 37 (3): 147-155.

Odero D.C., Mesbah A.O., Miller S.D., Kniss A.R. 2009. Venice mallow (Hibiscus trionum) interference in sugar beet. Weed Technology 23 (4): 581-585.

Odero D.C., Mesbah A.O., Miller S.D., Kniss A.R. 2010. Wild buckwheat (Polygonum convolvulus) interference in sugar beet. Weed Technology 24 (1): 59-63.

Pardo Iglesias A. 1990. La competencia de las malas hierbas con el cultivo de la cebolla (Allium cepa L.) en siembra directa: Predicción de pérdidas y escarda química. [Competition between weeds and direct seeded onion (Allium cepa L.): Predicting losses and chemical weeding]. Ph.D. thesis, Higher Technical School of Agricultural Engineering of
Madrid, Polytechnic University of Madrid, Madrid, Spain, 157 pp. (in Spanish)

Pujadas Salva A. 1986. Flora arvense y ruderal de la provincia de Córdoba. [Agrestal and ruderal flora in Córdoba (Spain)]. Ph.D. thesis, The Higher TechnicalSchool of Agricultural Engineering, University of Córdoba, Córdoba, Spain, 629 pp. (in Spanish)

Recasens J. 1994. Flora arvense en los cultivos de frutales. [Weed flora in fruit crops]. Phytoma 63: 57-62. (in Spanish)

Romero R., Zúnica L. R. 1993. Estadística (Proyecto de Innovación Educativa). [Statistics (Educational Innovation Project)]. UPV, Servicio de Publicaciones, SPUPV-94637, Valencia, Spain, 213 pp. (in Spanish)

Saavedra M. 1987. Estudio de las comunidades de flora arvense (malas hierbas) en el Valle Medio del Guadalquivir. [Weed flora in the Middle Valley of the Guadalquivir, Spain]. Ph.D. thesis, The Higher Technical School of Agricultural Engineering, University of Córdoba, Córdoba, Spain, 207 pp. (in Spanish)

Salehi F., Esfandiari H., Mashhadi H. R. 2006. Critical period of weed control in sugar beet in Shaheekord Region. Iranian Journal of Weed Science 2 (2): 1-12.

Scott R.K., Wilcockson S.J., Moisey F.R. 1979. The effects of time of weed removal on growth and yield of sugar beet. Journal of Agriculture Science 93 (3): 693-709.

Suso M.L., Cavero J., Fernández-Quintanilla C., González-Andújar J.L., González-Ponce R., Medina A., Pardo A., Salas M.L., Sánchez del Árco M.J., Santin I., Torner C., Zaragoza C. 1999. Conclusiones de los trabajos sobre la competencia de las malas hierbas con los cultivos de regadío en España. [Conclusions of some Spanish works on weed and irrigated crop competition]. p. 213-219. In: Proceedings of the 7th Spanish Weed Science Congress Logroño, Spain, 23-25 November 1999, 462 pp. (in Spanish)

Weaver S.E., Tan C.S. 1983. Critical period of weed interference in transplanted tomatoes (Lycopersicon esculentum): growth analysis. Weed Science 31 (4): 476-481.

Weaver S.E. 1984. Critical period of weed competition in three vegetable crops in relation to management practices. Weed Research 24 (5): 317-325. 